\title{
Menologion kijowskiego ewangeliarza pełnego z 1707 roku (uwagi wstępne na przykładzie miesiąca wrzesień) ${ }^{*}$
}

\author{
Jerzy Ostapczuk \\ Wydział Teologiczny \\ Chrześcijańska Akademia Teologiczna w Warszawie \\ Polska \\ jostap@wp.pl; jostap@chat.edu.pl
}

\begin{abstract}
Jerzy Ostapczuk, Menologion of the Kiev full lectionary Gospel from the year 1707 (preliminary remarks on the month September), Elpis, 18 2016: 65-73.

Abstract: The article is devoted to the menologion of the only Cyrillic full lectionary Gospel printed by the Printing house of the Kiev Pechersk Lavra in the year 1707. It gives general description of its menologion with a special attention to the number of days for every month, local celebrations and saints (their presence or absence). A detailed analysis (based on liturgical and textological research) of the September in comparison with 18 other early printed tetragospels (printed to 1712 in different printing houses of Moscow, Vilnius, Lvov and Kiev) shows close relationship of the analyzed full lectionary only with two Gospels printed in Kiev at 1697 and 1712.

Streszczenie: Artykuł został poświęcony menologionowi znajdującemu się w jedynym cyrylickim starym druku Ewangeliarza pełnego wydanego Drukarni Kijowsko-Peczerskiej Ławry w 1707 roku. Zawiera ogólną charakterystykę części minejnej ze szczególnym uwzględnieniem liczby dni w poszczególnych miesiącach, lokalnych świąt oraz świętych (ich obecność lub opuszczenie). Jako materiał porównawczy wykorzystano 18 innych starych druków tetraewangelii (tłoczonych do 1712 roku w różnych zakładach drukarskich (w Moskwie, Wilnie, Lwowie i Kijowie). Szczegółowa (liturgiczna i tekstologiczna) analiza, ograniczona do miesiąca września, wskazała na bliskie podobieństwo omawianego lekcjonarza pełnego i dwóch innych tetraewangelii wydanych w Kijowie w latach 1697 i 1712.
\end{abstract}

Keywords: early printed lectionary gospel, menologion, calendar, September, Kiev, 1707

Słowa kluczowe: stary druk ewangeliarza, menologion, kalendarz, wrzesień, Kijów, 1707

Ewangelia wydrukowana w 1707 roku w drukarni Ławry Peczerskiej w Kijowie zajmuje szczególne miejsce w historii cyrylickiego drukarstwa. Spośród wszystkich, tzn. ponad 200, cyrylickich starych druków z tekstem Dobrej Nowiny (to jest tetraewangelii, Nowego Testamentu i Biblii) jest to jedyny ${ }^{1}$ lekcjonarz pełny ${ }^{2}$. Ewangelia z 1707 roku uważana jest za jedno $\mathrm{z}$ najwspanialszych wydań drukarni Ławry Kijowskiej z okresu, kiedy jej kierownikiem był Josafat Krokowski (Тітов, 1918, s. 415)³. Z zajmującego trzy strony (f. 2-3r) wstępu - jego autorstwa ${ }^{4}$ - wiadomo, że geneza tego jedynego starego druku ewangeliarza pełnego

\footnotetext{
Niniejszy tekst został wygłoszony na Międzynarodowej Konferencji poświęconej 1000-leciu staroruskiego monastycyzmu na św. Górze Atos („Малий Афон” - Монастирі та чернецтво на закарпатті: традиції і сучасність, 3-4 październik 2015 r., Mukaczewo).

1 Do 1800 roku lekcjonarze były drukowane jeszcze trzy razy: w Uhercach (w 1620 roku), Łucku (w 1640 roku) i Lwowie (w 1706 roku). Były to jednak apostoły-ewangeliarze niedzielne, czyli księgi zawierające naprzemiennie ułożone czytania z Apostoła i perykopy z Ewangelii. Szerzej o nich zob. Ostapczuk, 2013, ss. 133-168; 2015b, ss. 159-201.

2 Ewangeliarz pełny został jeszcze wydrukowany w Drukarni Synodalnej w Moskwie w 1854 roku.

3 Josafat Krokowski był archimandrytą Ławry Kijowskiej od 1697 do 1707 roku (por. Тітов, 1918, ss. 402-424; Mironowicz, 2001, s. 320).

4 Тітов, 1918, ss. 411-412.415. Wykaz przedmów napisanych przez J. Krokowskiego zob. Шевчук, 2012, ss. 294-295.
}

związana jest z darem pewnego archimandryty ze Świętej Góry Atos (podróżującego, najprawdopodobniej, z jałmużną (zbiorem pieniężnym)). We wstępie zapisano, że: Нtкїй

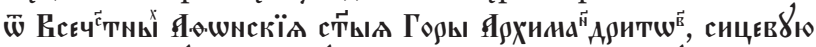

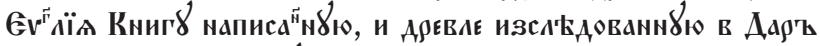

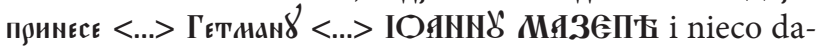

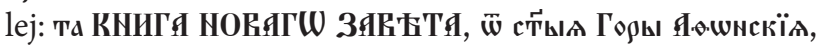
в Даръ принєсеннал.

Typologicznie Ewangeliarz kijowski z 1707 roku, który jest lekcjonarzem pełnym (le), odpowiada praktyce liturgicznej monasterów św. Góry Atos, w których nabożeństwa eucharystyczne, tzn. liturgie, celebrowane były codziennie. Także i dziś większość zachowanych w zbiorach monasterów atoskich rękopiśmiennych ewangeliarzy ${ }^{5}$ to aprakosy pełne (Ostapczuk, 2015a, ss. 305-306).

W lekcjonarzach, które na gruncie słowiańskim określane są mianem aprakosów, wyróżnia się dwie (lub niekiedy nawet trzy) główne części. Ułożenie w nich tekstów nowotestamentowych odpowiada porządkowi roku liturgicznego (a nie powszechnie przyjętej kolejności czterech Ewangelii (Mateusza, Marka, Łukasza i Jana)). Perykopy

5 Statystyki rękopiśmiennych ewangelii przechowywanych w monasterach św. Góry Atos zob. Ostapczuk, 2015a, ss. 304-307. 
ewangeliczne cyklu triodnego (czyli świąt ruchomych) odpowiadają pierwszej części lekcjonarzy - synaksarionowi, który rozpoczyna się perykopą święta Zmartwychwstania Pańskiego. Perykopy ewangeliczne cyklu minejnego (czyli świąt stałych) odpowiadają drugiej części lekcjonarzy - czyli menologionowi ${ }^{6}$, który rozpoczyna się 1 września i kończy 31 sierpnia. Zawarte w tych dwóch częściach (podobnie jak i perykopy jutrzni niedzielnych) aprakosów perykopy ewangeliczne, czytane były kolejno, według swego porządku.

O takim nietypowym, jak na owe czasy, i praktycznym $^{7}, \mathrm{z}$ liturgicznego punktu widzenia (jak poinformował I. Mazepa metropolitę), układzie tekstu Dobrej Nowiny w druku Ewangelii kijowskiej z 1707 roku również wspominano we wstępie: в сєй оүБо Книз' Єө

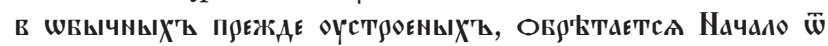

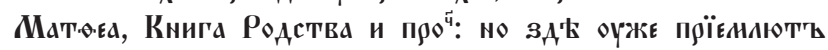

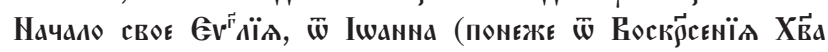

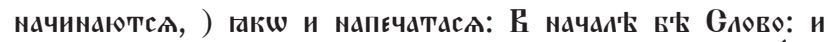

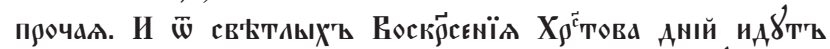

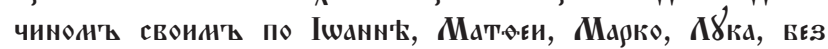
вслкагШ в зачала

W Ewangelii kijowskiej z 1707 roku fragmenty ewangeliczne zajmują 315 kart $^{8}$. W pierwszej części - synaksarionie (karty 1-216v) - znajdują się perykopy na wszystkie ${ }^{9}$ dni w roku liturgicznym. W jego drugiej części - menologionie (karty 217-310v), który jest przedmiotem niniejszej publikacji - znajdują się perykopy ewangeliczne nie na wszystkie dni w roku liturgicznym.

Święta i święci cyklu minejnego cerkiewnosłowiańskich rękopisów Ewangelii (i niekiedy też innych ksiąg) były przedmiotem zainteresowań uczonych już od połowy XIX wieku (Древнейшие русские святи,ы, ss. 485-517), np. K.I. Newostruew (Невоструев, 1997, ss. 5-649), J. Martinov (1863), G. Bulaszew (Булашев 1882); arcybiskup Sergiusz (Spasski) (Сергий архиепископ 1901) ${ }^{10}$. Również w następnym stuleciu menologiony rękopiśmiennych Ewangelii były przedmiotem badań niektórych uczonych (Е. Kocewoj i A. Atanasowa (Коцева, 1985, ss. 104-111;

\footnotetext{
6 O nazwach pierwszej i drugiej części ewangeliarzy zob. Лосева, 2001a, ss. 24-26; Ostapczuk, 2010, ss. 29-31.

O minusach aprakosowego układu tekstu Ewangelii w przedmowie do Ewangelii z 1707 roku napisano: а понєже по чинठ Цјркви сттон Восточнои

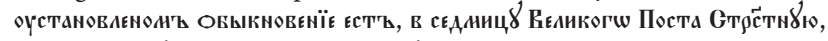

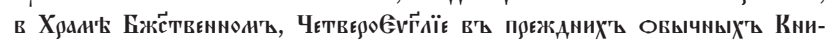

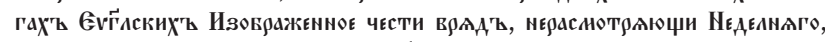

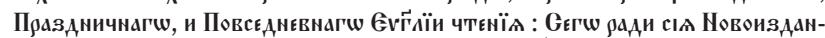
наA GrЃ,

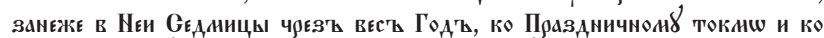

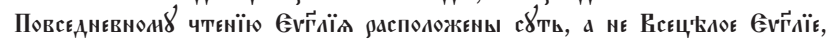

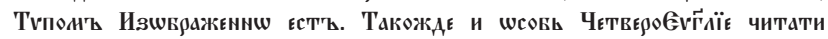

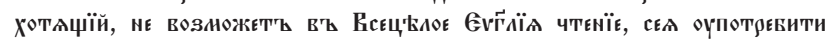
Книги..

8 Obok dwóch głównych części - synaksarionu i menologionu - w Ewangelii z 1707 roku znajdują się jeszcze: 11 perykop Ewangelii jutrzni niedzielnych (f. 311-315); Ewangelia za zmarłych (f. 315) i Ewangelie wspólne świętym czytane (f. $315 v$ ).

9 Wyjątkiem są dni, w które nie celebruje się liturgii, np. wtorek i czwartek w tygodniu poprzedzającym Wielki Post.

${ }_{10}$ Charakterystyka menologionów Ewangelii (greckich i słowiańskich) zob. Сергий архиепископ, 1901, ss. 88-135 (Т. 1).
}

Коцева, Атанасов, 1991, ss. 292-319; 1993, ss. 214-241); N. Kowiaziny (Ковязина, 1997, ss. 31-52; 1998, ss. 51-61); О. Losewoj (Лосева, 1995, ss. 46-54; 1999a; 1999b; 2001a; 2001b, ss. 14-36; 2003, ss. 132-141); N.A. Meszczerskiego (Мещерский, 1997, s. 155); H. Miklasa (1999); L. Skomorochowej-Wenturili (Скоморохова-Вентурили, 1985, ss. 122-131); D. Stefanowicia (Стефановић, 1989, ss. 140152); A.A. Turilowa (Турилов, 2010, ss. 117-146); C. Wakalerijskiej (Вакалерийска, 1994, ss. 58-68); L.P. Żukowskiej (Жуковская, 1993, ss. 81-87)). Ostatnią monumentalną pracę poświęconą cyklowi minejnemu 152 cerkiewnosłowiańskich rękopiśmiennych Ewangelii ${ }^{11}, \mathrm{z}$ okresu od XI do XIV wieku, opublikowała O. Losewa ${ }^{12}$. Dotychczasowe publikacje o menologionach dotyczyły wyłącznie rękopiśmiennych kodeksów Ewangelii, różnych pod względem typologicznym (tetraewangelie; lekcjonarze: pełne, krótkie, ultrakrótkie). Menologiony starodrucznych Ewangelii (od 1512 do 1800 roku) i młodszych (po 1801 roku) nie doczekały się jeszcze swego opracowania. Ich naukowa charakterystyka byłaby szczególnie pomocna w badaniach drugiej części lekcjonarza kijowskiego z 1707 roku.

Dotychczasowe badania cyklu minejnego pokazały, że wśród zachowanych współcześnie najstarszych rękopiśmiennych zabytków Ewangelii (z XI-XIII w.) brak jest dwóch kodeksów mających taki sam menologion (Сергий архиепископ, 1901, s. 28 (т. 1); por. Жуковская, 1993, ss. 81-87), tzn. wykaz wszystkich tych samych świąt i świętych. Manuskrypty Dobrej Nowiny z podobnymi menologionami są dużą rzadkością (Лосева, 2001a., ss. 5.37; 2001b, s. 14) ${ }^{13}$ i pochodzą przeważnie z XIV wieku (Лoceва, 2001b, s. 14).

Liczba świąt i świętych w menologionach słowiańskich Ewangelii zwiększała się z każdym stuleciem. Menologiony rękopisów Dobrej Nowiny z XII wieku - w porównaniu do manuskryptów z wieku XI - mają 278 nowych świąt; menologiony z XIII wieku - 177 i z wieku XIV - 51 (Лосева, 2001b, s. 15).

Różnorodność cyklu minejnego spowodowana jest kilkoma czynnikami, a mianowicie (Лосева, 2001a, s. 5.44; 2001b, s. 20):

a) wykorzystaniem różnych źródeł do kompozycji nowego menologionu, na których kształt wpływ miały ich protografy o różnym pochodzeniu (proweniencji) i historii;

b) lokalnymi uwarunkowaniami liturgicznymi, w których powstał dany menologion, oraz ustawem liturgicznym.

Dlatego też analiza świąt i świętych wymienionych w cyklu minejnym ma duże znaczenie nie tylko w przypadku badań konkretnego zabytku, lecz także w badaniach dotyczących historii, liturgii, etnografii i kultury. Zawarte $\mathrm{w}$ menologionach informacje dotyczą m.in. (Лосева, 2001a, s. 30): konkretnych osób (świętych), wydarzeń hi-

\footnotetext{
11 Były one także przedmiotem jej rozprawy doktorskiej pt. Месяцесловы древнерусских Евангелий XI-XII веков (Лосева, 1999а).

12 Oprócz 152 Ewangelii wykorzystała ona $\mathrm{w}$ badaniach również 26 Apostołów (Лосева, 2001a, ss. 7.11).

13 O podobnych cyklach minejnych w różnych rękopisach Ewangelii zob. Лосева, 2001a, ss. 37-43.
} 
storycznych $^{14}$, cudów ${ }^{15}$, tragedii ${ }^{16}$, zjawisk przyrody ${ }^{17}$, z uwzględnieniem niekiedy dokładnej daty (a nawet godziny) i innych informacji - czasami nawet dokładniejszych niż w Kronikach (Лосева, 2001a, s. 6).

W przypadku kodykologicznych badań rękopiśmiennych zabytków analiza lokalnych świąt i świętych zawartych w cyklu minejnym może mieć fundamentalne znaczenie dla datacji i miejsca powstania tych zabytków (Лосева, 2001a, ss. 6-7).

Cykle minejne zdecydowanej większości rękopiśmiennych Ewangelii to tzw. menologiony niepełne, w których opuszczone są niektóre dni w poszczególnych miesiącach (Лосева, 2001a, s. 31). Najmniejsza liczba świąt w menologionie wymieniana jest w lutym, marcu i kwietniu (co wiąże się z nabożeństwami wielkopostnymi ${ }^{18}$ ), zaś największa we wrześniu i styczniu (Лосева, 2001a, s. 32).

Najstarszy pełny menologion, tzn. taki, który ma wymienione wszystkie dni dwunastu miesięcy, znajduje się w Ewangeliarzu Mścisława (Лосева, 2001a, s. 31) - wymienionych zostało tam 418 świąt ${ }^{19}$. Część minejna Ewangelii powstałych w elitarnych (np. książęcych czy metropolitalnych) skryptoriach obfituje w dużą liczbę świąt i świętych, natomiast Ewangelie pochodzące z mniej znaczących ośrodków piśmienniczych (ale będące np. własnością hierarchów) mogą mieć w menologionie tylko najbardziej znane święta (Лосева, 2001a, s. 33) ${ }^{20}$.

Po przebadaniu 152 rękopiśmiennych Ewangelii i 26 Apostołów O. Losewa stwierdziła, że w części minejnej tych zbytków znalazło się 1040 świąt i świętych, z czego 657 w Ewangeliach i Apostołach, 275 tylko w Ewangeliach i 108 tylko w Apostołach (Лосева, 2001a, s. 33). Niewiele ponad $1 / 4$ tej całości to wyjątkowo rzadkie święta i święci, wymienione tylko w jednym rękopisie; zaś 100 wymienionych było tylko w dwóch rękopisach.

Geneza wydanej w 1707 roku w Kijowie Ewangelii związana jest - jak już wspomniano - z ewangeliarzem przywiezionym ze Świętej Góry Atos. Przekazany przez I. Mazepę J. Krokowskiemu atoski lekcjonarz miał posłużyć jako wzór do przygotowania nowego druku Ewangelii.

Druk kijowski z 1707 roku to ewangeliarz pełny (le) i pod względem typologicznym jest zapewne dokładnym odbiciem atoskiego lekcjonarza. W bibliotekach na Górze Atos wśród ewangeliarzy (w przypadku pominięcia tetraewangelii) dominują właśnie aprakosy pełne, a inne typy

\footnotetext{
14 Np. zwycięstwa wojenne, napady wrogów, założenie i splądrowanie miast, poświęcenie świątyń (Лосева, 2001a, s. 6.30).

15 Np. ukazanie się krzyża na niebie (Лосева, 2001a, s. 30).

16 Np. pożar, powódź (Лосева, 2001a, s. 6.30).

17 Np. trzęsienia ziemi, wybuchy wulkanów (a dokładnie opad z nieba wulkanicznego pyłu) (Лосева, 2001a, ss. 6.30).

18 Wielki post może rozpocząć się najwcześniej 2 lutego, najpóźniej 8 marca.

19 Są jednak jeszcze bardziej obszerne menologiony, np. zawierające aż 466 świąt i świętych (por. Лосева, 2001a, ss. 31-32). Żaden z aprakosów pełnych XII-XIII wieku nie ma pełnego menologionu, a z XIV wieku tylko 4 (Rm-107, Rm-108, Sn-64, Eg-108) (Лосева, 2001a, s. 32). Z tetrów tylko menologion Ewangelii Galickiej jest pełny, który ma aprakosowe pochodzenie (Лосева, 2001a, s. 32).

20 O. Losewa wskazała tu na 80 świąt (Лосева, 2001a, s. 34).
}

lekcjonarzy (np. krótkie, sobotnio-niedzielne itd.) to wyłącznie pojedyncze egzemplarze.

Odpowiedź na pytanie, czy w ogóle i na ile cykl minejny Ewangelii kijowskiej z 1707 roku jest dokładnym odbiciem atoskiego lekcjonarza, jest w tej chwili niemożliwa. Przywieziony z Góry Atos i ofiarowany I. Mazepie ewangeliarz, który posłużył jako wzór do druku, nie został dotychczas zidentyfikowany. Skład świąt i świętych cyklu minejnego Ewangelii kijowskiej może w pełni lub tylko częściowo i to w różnych jego częściach (tzn. miesiącach) odzwierciedlać skład menologionu ewangeliarza atoskiego. Ewangelia wydrukowana w 1707 roku miała zapewne trafić do duchownych chrześcijan wschodniosłowiańskich mających swe lokalne święta i świętych o szczególnym tylko dla nich znaczeniu. Mimo że jej współcześnie zachowane egzemplarze znajdują się głównie na terenie Ukrainy, nie można wykluczyć wykorzystania tej kijowskiej Ewangelii na innych ziemiach (np. Słowian południowych czy Górze Atos). Dlatego też należy uwzględnić fakt, że wydawcy mogli wprowadzić do części minejnej wspomnienia lokalnych wschodniosłowiańskich świętych i świąt, pomijając tym samym mało lub niepopularne u nich święta (np. południowosłowiańskie, greckie czy łacińskie) wymienione w Ewangelii atoskiej ${ }^{21}$. Być może menologion Ewangelii kijowskiej w ogóle (w przypadku pominięcia niektórych świąt i świętych o ogólnochrześcijańskim charakterze) nie odzwierciedla składu miesięcznej części Ewangeliarza atoskiego. Niewykluczone, że do kompozycji kijowskiego druku posłużono się wykazem świąt i świętych innej dostępnej wydawcom rękopiśmiennej Ewangelii lub nawet - co bardziej prawdopodobne - drukowanej. Przecież w drukarni Ławry kijowskiej Ewangelię po raz pierwszy wydano już w 1644 r. (żaden jej egzemplarz nie zachował się (Гусева, 1997, s. 120)), zaś po raz drugi w 1697 roku. Do 1707 roku, gdy pominiemy druki południowosłowiańskie, cyrylickie tetraewangelie były drukowane prawie 50 razy (Ostapczuk, 2013, ss. 137-143).

Wstępną charakterystykę części minejnej Ewangelii kijowskiej z 1707 roku należy traktować jako wprowadzenie do badań tekstologicznych i liturgicznych, w których jako materiał porównawczy wykorzystać należy tetraewangelie (oraz inne księgi zawierające miesięczny wykaz świąt i świętych) drukowane do 1707 roku (i być może w I poł. XVIII w.) w różnych wschodniosłowiańskich ośrodkach drukarskich (tzn. Moskwa, Wilno, Lwów i Kijów). Przeprowadzenie takich badań porównawczych wskaże, być może, na stopień podobieństwa cyklu minejnego Ewangelii z 1707 roku i pozostałych drukowanych (do tego roku) tetrów, które mogły być wykorzystane w pracy wydawców kijowskich, a tym samym, być może, pozwoli uzyskać ogólne informacje o składzie świąt i świętych niezidentyfikowanego dotychczas atoskiego lekcjonarza.

Każda z dwunastu części menologionu, czyli miesięcy, rozpoczyna się informacją o nazwie miesiąca i liczbie dni,

\footnotetext{
W skład menologionów nie tylko były wprowadzane nowe święta i święci, lecz były one też z niego usuwane (Лосева, 2001a, s. 31; 2001b,
} s. 29). 


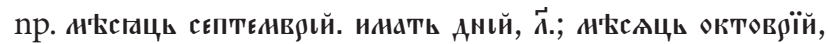
ина̄ дний, Һ̆d. Użyte tam zostały starożytne nazwy miesięcy, które były powszechnie używane również $\mathrm{w}$ tradycji

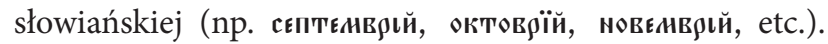
W Ewangelii kijowskiej brak jest słowiańskich nazw miesięcy, nр. ноүрьтаяь (marzec), пюотонь (czerwiec), występujących niekiedy w tradycji rękopiśmiennej.

Każdy dzień części minejnej ma następującą standardową (Por. Лосева, 2001a, s. 30) kompozycję:

- numer dnia, po którym czasami podana jest także

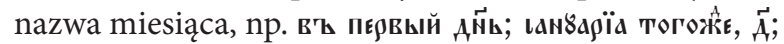

- wykaz świąt, świętych lub wydarzeń cerkiewnych czy państwowych, których pamięć przypada tego dnia, np.:

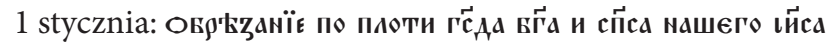

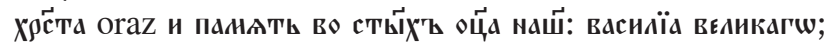

- informacje liturgiczne o nabożeństwie, tzn. na jakie nabożeństwo (nieszpory i jutrznię (nie zawsze obecne) lub liturgię) przeznaczona jest perykopa ewangeliczna, np.: на оүтрени і на льтьягін;

- informacje o Ewangelii, tzn. imię Ewangelisty i nu-

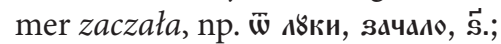

- w przypadku zapisania kilku wspomnień liturgicznych jednego dnia, przed kolejnym fragmentem ewange-

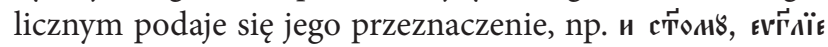
ші льки, здчдль, ка.

W związku ze specyfiką lekcjonarzy, polegającą na możliwości zapisania perykopy ewangelicznej w kilku miejscach (ponieważ ten sam fragment może być czytany na nabożeństwach kilka razy w roku), czasami zamiast informacji o perykopie ewangelicznej (imię Ewangelisty i numer zaczała) może być podana informacja o miejscu, gdzie wcześniej dany fragment został zapisany (np.: 1 grudnia, w dniu pamięci św. Barbary i św. Jana Damasceńskiego za-

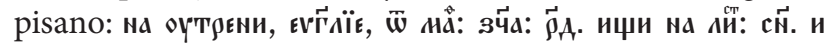

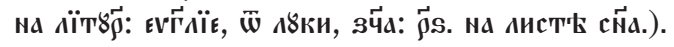

Niekiedy też podawane są także inne dodatkowe informacje liturgiczne, związane z praktyką czytania perykop ewangelicznych i dniem tygodnia, kiedy przypada świę-

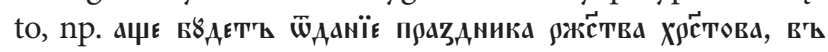

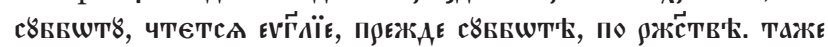

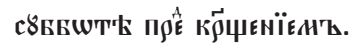

W menologionie Ewangelii kijowskiej z 1707 roku brak jest początkowych wierszy, występujących niekiedy w drukowanych tetraewangeliach, $\mathrm{z}$ troparionów świątecznych, sticherionów czy alleuariów.

W Ewangelii kijowskiej nie ma wymienionego żadnego święta czy świętego, przy których, oprócz podstawowej informacji (np. nazwa lub imię), nie byłoby żadnych dodatkowych danych ${ }^{22}$, tzn. informacji o perykopie ewangelicznej czy odsyłacza do miejsca, gdzie powinna się ona znajdować. Wszystkie wymienione w cyklu minejnym święta i święci mają informację dotyczącą lektury konkretnego fragmentu Ewangelii.

Cykl minejny Ewangelii kijowskiej z 1707 roku nie jest menologionem pełnym. W każdym z miesięcy opuszczono

\footnotetext{
22 W ewangeliarzu archangielskim z 1092 roku takich miejsc jest 4. Są to święta typowe dla tradycji zachodniej (łacińskiej) (Лосевa, 2001a, s. 31).
}

po kilka dni: 27 w marcu ${ }^{23} ; 26$ w kwietniu ${ }^{24} ; 23$ w lutym ${ }^{25}$; $21 \mathrm{w}$ maju ${ }^{26} ; 20$ dni w czerwcu $^{27}$ i sierpniu ${ }^{28}$; 18 dni w listopadzie $^{29} ; 17$ dni w październiku ${ }^{30}$ i grudniu ${ }^{31} ; 15$ dni w lip$\mathrm{cu}^{32} ; 14$ dni w styczniu ${ }^{33}$ i 10 we wrześniu ${ }^{34}$.

Najmniejszą liczbę dni w cyklu minejnym mają następujące miesiące: marzec i kwiecień - tylko po 4 dni, a luty -5 .

Nie powinien więc dziwić fakt, że jeszcze w XVIII wieku, mimo rozwiniętej już w tym czasie tradycji liturgicznej, w Ewangelii kijowskiej został umieszczony niepełny menologion. O. Losewa wskazała, że niepełne menologiony występują nie tylko w najstarszych rękopisach Ewangelii, lecz również i tych młodszych (Лосева, 2001a, ss. 32-33). Analogiczna sytuacja ma również miejsce w drukowanych od 1512 roku tetraewangeliach.

$\mathrm{Z}$ wymienionych przez $\mathrm{O}$. Losewą 80 świąt stanowiących główny trzon przebadanych przez nią 152 Ewangelii (Лосева, 2001a, ss. 34-35) w druku kijowskim nie zostały wymienione tylko trzy: pamięć męczenników Sergiusza i Bakcha (7.10), wlk. męczennika Mina (11.11) oraz Klemensa, papieża rzymskiego (25.11). Opuszczenie w menologionach wymienionych dwóch dat listopadowych (11 - św. Mina i 25 - św. Klemensa Rzymskiego) tłumaczy się wpływem w poł. XIV wieku typikonu jerozolimskiego na ukształtowaną w Konstantynopolu praktykę liturgiczną ${ }^{35}$. Wynikiem tego było m.in. wprowadzenie na stałe do cyklu minejnego w dniu 5.12 pamięci św. Sawy Uświęconego, co potwierdza również Ewangeliarz kijowski.

Spośród dni wymienionych w cyklu minejnym Ewangelii kijowskiej należy zwrócić uwagę na:

- święta charakterystyczne dla typikonu jerozolimskiego $^{36}$ : poświęcenie Świątyni Zmartwychwstania Pańskiego (13.09 \{335 r. $\}^{37}$ ); św. Ojców zamordowanych na Synaju i w Raifie (14.01) i przypadające na ten sam dzień

\footnotetext{
23 W marcu opuszczono następujące dni: 1-8, 10-16, 18-24, 27-31.

24 W kwietniu opuszczono następujące dni: 1-22, 24, 26, 28-29.

25 W lutym opuszczono następujące dni: 1, 4-7, 9-11, 13-23.

26 W maju opuszczono następujące dni: 1, 4-6, 11-14, 16-19, 22-24, 26-31.

27 W czerwcu opuszczono następujące dni: 1-7, 10, 13, 16-18, 20-23, 25-29.
}

${ }^{28}$ W sierpniu opuszczono następujące dni: 3-5, 7-8, 10-13, 17-23, 26-28, 30.

29 W listopadzie opuszczono następujące dni: 2-3, 5, 7, 9-11, 15, 18-20, 22-23, 25-29.

30 W październiku opuszczono następujące dni: 2, 4-5, 7-10, 12-13, 15, $17,19,24-25,29-31$.

31 W grudniu opuszczono następujące dni: 2-4, 7-8, 10-12, 14-16, 18-19, $22-23,28,30$.

32 W lipcu opuszczono 15 dni: 3-4, 6-7, 9, 12, 14, 17-19, 21, 23, 26, 29-30.

33 W styczniu opuszczono następujące dni: 2-3, 8-10, 12-13, 15, 19, 21, 23-24, 26, 28.

34 We wrześniu opuszczono następujące dni: 7, 12, 17-19, 21-22, 27, 29-30.

35 W Ewangelii kijowskiej pod datą 11 października jest święto św.św. Ojców VII Soboru Powszechnego, które jest w tym dniu obchodzone zgodnie z Typikonem Świątyni Mądrości Bożej i Studyjskim (Лосева, 2001a, s. 174)

36 W Ewangelii z 1707 roku wymienionych zostało tylko kilka świąt z wielu charakterystycznych dla Typikonu jerozolimskiego zob. Ęlęlëěčäçí, 1912, ss. 50-54.116-150.

37 Święto to nie występuje w słowiańskich menologionach do połowy XIV wieku. W menologionach konstantynopolitańskich pojawia się sporadycznie od XI w. Zob. Лосева, 2001b, s. 26. 
zakończenie święta Chrztu Pańskiego (14.01) (Por. Лосева, 2001a, s. 248);

- święta charakterystyczne dla typikonu Świątyni Mądrości Bożej w Konstantynopolu: trzęsienie ziemi w Konstantynopolu (26.10 \{740 r.\}); pamięć św.św. Ojców VII Soboru Ekumenicznego (niedziela po 11.10) (Рог. Лосева, 2001a, s. 175); patriarchów Konstantynopola ${ }^{38}$ [św. Pawła Wyznawcy (6.11 \{zm. w 350 r.\}); św. Jana Złotoustego (13.11); św. Metodego (14.06 \{zm. w 847 r.\})];

- wielu świętych wschodniosłowiańskich ${ }^{39}$, np.: św. Eufrozyna z Suzdala (25.10 \{zm. ok. 1250 r.\}); św. Sergiusz, cudotwórca Wałaamski (25.09 \{zm. ok. 1353 r.\}), św. Makary, ihumen Kolaziński (17.03 \{zm. $1483^{40}$ r.\}); św.św. Antoni (10.07) i Teodozjusz (3.05 i i 14.08) Peczerscy; św. Sergiusz z Radoneża (5.07); św. Olga ${ }^{42}$ (11.07 \{zm. w 969 r.\}); św. Włodzimierz (15.07); św.św. Borys i Gleb (24.07); metropolici moskiewscy ${ }^{43}$ : św. $\operatorname{Piotr}^{44}$ (21.12 \{zm. w 1326 r.\}); św. Aleksy ${ }^{45}$ (12.02 \{zm. w 1372 r.\} i 20.05), św. Jonasz (15.06 \{zm. w $1461^{46}$ r.\}) oraz święto ikony Bogurodzicy Smoleńskiej (28.07);

- uwzględnienie z serbskich świętych (por. Лосева, 2001b, s. 28) tylko św. Paraskiewy Epiwatskiej (Serbskiej) (14.10) i pominięcie m.in. św. Sawy Serbskiego (12.01), św. Symeona Serbskiego (Stefana Nemanię) (13.02) czy św. Arseniusza (28.10 i 30.08);

- opuszczenie św. Klemensa Rzymskiego (25.11) i uwzględnienie św. męczennika Hipolita Papieża Rzymu (30.01 \{zm.w 258 r.\});

- opuszczenie wszystkich nielicznych (por. Лосева, 2002b, s. 30) świąt i świętych czeskich występujących w słowiańskich rękopiśmiennych Ewangeliach;

- opuszczenie najstarszych cyrylo-metodiańskich świą ${ }^{47}$, tzn. 30.01 - odnalezienie w Chersonie przez św.św. Cyryla i Metodego relikwii św. Klemensa Papieża rzymskiego (861 r.); 14.02 - dzień śmierci św. Cyryla (869 r.); 6.04 - dzień śmierci św. Metodego (885 r.).

$\mathrm{Z}$ wymienionych dni na szczególną uwagę zasługuje uwzględnienie w cyklu minejnym uroczystości zakończenia święta Chrztu Pańskiego: в тойжє Ап̆ (tzn. 14 stycz-

\footnotetext{
38 Niektórzy zostali pominięci, np. święty Jan Postnik (2.09), choć wspomniany jest on w tetrach moskiewskich (z lat 1553/54, 1627, 1628, 1689, 1703 ), wileńskim (z 1600 r.) i kijowskich (z lat 1697 i 1712).

39 Do końca XIV wieku do menologionów rzadko wprowadzani byli wschodniosłowiańscy święci i święta. Liczba świąt i świętych wzrastała wraz $\mathrm{z}$ kolejnymi kanonizacjami, a proces ich wprowadzania do menologionów nie był regularny (Лосева, 1999b, ss. 40.47).

40 Kanonizowany w $1547 \mathrm{r}$.

${ }^{41}$ Wspomnienie św. Teodozjusza w menologionach Ewangelii pojawia się dopiero w XIII w. Dużo częściej jego imię spotyka się w Ewangeliach bułgarskich i serbskich, szczególnie z XIV w. Por. Лосева, 1999b, s. 23.

42 Jej pamięć pojawia się w menologionach Ewangelii dopiero od koń. XIV w. (Лосева, 1999b, ss. 40-41).

43 Opisani są jako: яитропольта києвскаго и всєка россьи.

44 Jego pamięć pojawia się w menologionach Ewangelii od koń. XIV w. (Лосева, 1999b, ss. 40-41).

45 Kanonizowany w 1448 roku.

46 Kanonizowany w 1472 r. (wtedy stwierdzono, że jego ciało nie uległo rozkładowi)

47 Święta te w menologionach słowiańskich Ewangelii od XI do XIII wieku pojawiały się coraz rzadziej, a zaniknęły prawie całkowicie w XIV w. (Лосева 2001b: 27-28).
}

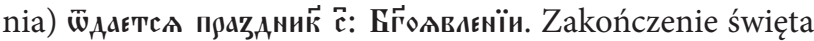
Teofanii w dniu 14 stycznia odpowiada Typikonowi jerozolimskiemu, ponieważ według typikonu studyjskiego, uroczystość ta przypadała 13 stycznia (Лосева, 2001a, s. 248; 2001b, s. 23). Święto to, jak i wyrażenie воса'\$дованїє

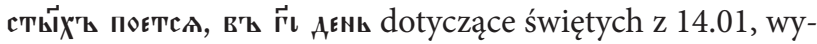
stępuje tylko $\mathrm{w}$ dwóch drukach tetraewangelii kijowskich $\mathrm{z}$ lat 1697 i 1712. Zarówno święto to, jak i wyrażenie, jest pominięte w późniejszych tetrach kijowskich (np. z 1733 r.) i Ewangeliach pochodzących $z$ innych ośrodków drukarskich (Moskwa, Wilno czy Lwów). Wyznaczenie końca święta Teofanii na dzień 14 stycznia tylko w Ewangeliach kijowskich z lat 1697, 1707 i 1712 świadczy o bliskości tradycji liturgicznej zawartej w ich cyklach minejnych.

O tym, że menologion Ewangelii kijowskiej z 1697 roku nie został dokładnie odzwierciedlony $\mathrm{w}$ Ewangelii z 1707 roku świadczy wykaz świąt i świętych oraz ich opis, np. w dniu 10 lipca. W wydaniu z 1697 (oraz 1712) roku wymieniono:

a) 45 męczenników z Nikopolis armeńskiego;

b) złożenie szaty (chitonu) Chrystusa w Moskwie

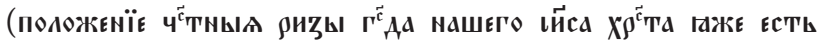

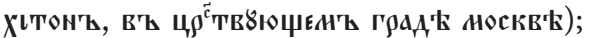

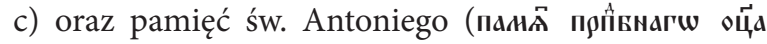

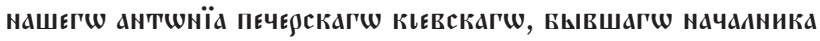

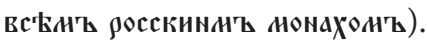

W Ewangelii kijowskiej z 1707 roku pierwsza pamięć opisana została tymi samymi słowami, druga - złożenie szaty Chrystusa w Moskwie - pominięta w całości, a w trzeciej opuszczono drugą część informacji (tzn. Бывшагш

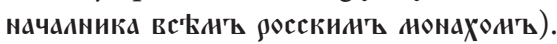

Ze względu na liczbę świąt i świętych znajdujących się w menologionie, składającym się z 12 miesięcy, charakter publikacji i ograniczony dostęp do starych druków tetraewangelii niemożliwe było przeprowadzenie szczegółowej analizy wszystkich informacji zawartych w drugiej części Ewangelii z 1707 roku. Dlatego też badania tekstologiczne zostały ograniczone do pierwszego miesiąca menologionu, tzn. września, i 18 cyrylickich tetraewangelii wydanych w różnych ośrodkach drukarskich, tzn. w Moskwie - łącznie $9(1553 / 1554,1627,1628,1644,1648,1651,1663,1689$ i 1703); w Wilnie (w 1600 r. (bez sygnatur)); we Lwowie łącznie $6(1636,1644,1665,1670,1690$ i 1704) i w Kijowie łącznie 2 (1697 i 1712).

Tytuł części minejnej Ewangelii kijowskiej z 1707 roku ${ }^{48}$ tylko nieznacznie różni się od dwóch pozostałych tetrów kijowskich (z lat 1697 і 1712). W miejscu słowa в нєм'ъже zapisano сказ8. $\mathrm{A}$. W pozostałych tetraewangeliach różnice są już bardziej wyraziste ${ }^{49}$.

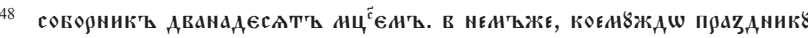

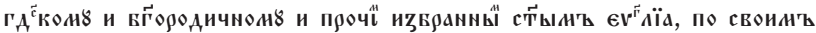

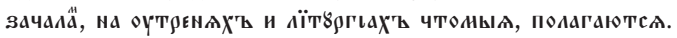

49 Np.:

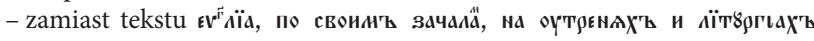
чтодыл, полагаютел w trzech tetrach moskiewskich $(1663,1689$ i 1703) zapisano єv

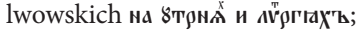

- zamiast tekstu ковнвждо праздник8 tylko w trzech tetrach moskiewskich (1663, 1689 і 1703) zapisano праздников’ь.
} 
Minejny wykaz świąt i świętych Ewangelii kijowskiej z 1707 roku wskazuje na analogie nie tylko do dwóch pozostałych tetrów kijowskich (z lat 1697 i 1712), lecz również do moskiewskich z lat 1689 i 1703. Np. 1 września

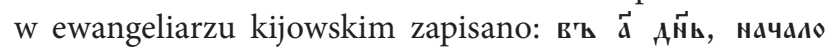

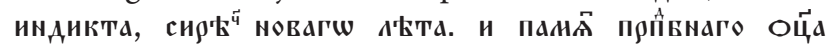

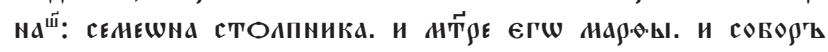

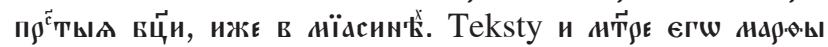

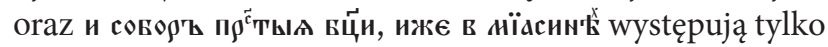
we wskazanych tetrach moskiewskich, choć ten drugi $(\mathrm{z}$

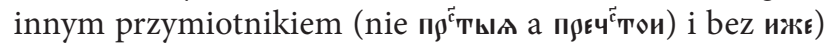
również w drukach lwowskich Michała Ślozki (z lat 1644 i 1665$)^{50}$.

Jednak już w następnym dniu - 2 września - widoczne są różnice między Ewangelią kijowską z 1707 roku a dwoma tetrami kijowskimi (z lat 1697 i 1712) i dwoma moskiewskimi (z lat 1689 i 1703). Pamięć św. Jana Postnika (пюєподовнаго оц̆а нӓ: ๘шӓна постника) poświadczona już w najstarszym tetrze moskiewskim (z 1553/54 roku) oraz tych z lat 1689 i 1703 i dwóch kijowskich (z lat 1697 i 1712), została opuszczona w Ewangelii kijowskiej z 1707 $\operatorname{roku}^{51}$.

W dniu 3 września w Ewangelii kijowskiej wymieniony został tylko św. męczennik Antym. W pozostałych tetraewangeliach zapisano przy nim informację, że był on biskupem Nikomedii (єп்па ньконидиискагш), wymieniono również świętych Teoktysta i Eutymiusza ${ }^{52}$.

W dniu 4 września w Ewangelii kijowskiej wymieniony został tylko św. męczennik Babylas. W pozostałych tetraewangeliach zapisano ponadto przy nim informację, że był on $\mathrm{z}$ Antiochii ${ }^{53}$, gdzie był biskupem ${ }^{54}$, oraz wymieniono św. Mojżesza Proroka ${ }^{55}$.

W dniu 5 września w Ewangelii kijowskiej wymieniony został tylko św. Zachariasz, ojciec św. Jana Chrzciciela. W dwóch tetrach kijowskich (z lat 1697 i 1712) zapisano ponadto wspomnienie zabicia św. księcia Gleba (в тонжє

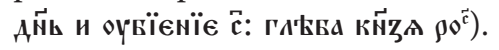

W dniu 6 września w Ewangelii kijowskiej wymieniony jest cud św. archanioła Michała. W pozostałych tetraewangeliach zapisano przy nim informację, że miał on miejsce

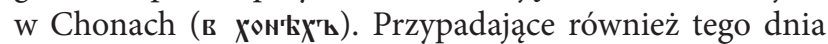
święta św. męczennika Eudoksjusza i św. Archipa zostały wymienione tylko w jednym tetrze moskiewskim z 1663 roku i dwóch kijowskich z 1697 i 1712 roku.

Dzień 7 września został w Ewangelii kijowskiej pominięty. Natomiast w pozostałych tetrach w tym dniu wspomina się wigilię święta Narodzenia Bogurodzicy, męczennika Sozonta i św. Jana, arcybiskupa Nowogrodu ${ }^{56}$.

W dniu 8 września w Ewangelii kijowskiej i wszystkich

\footnotetext{
50 W tych dwóch drukach M. Ślozki w dniu 1 września zapisano także św. Jozuego, syna Nuna (и панй̃ иис४са наvина).

51 Pamięć ta została również opuszczona w tetrach moskiewskich $\mathrm{z}$ lat $1644,1648,1651$ i 1663 oraz wszystkich lwowskich.

52 W tetrach moskiewskich począwszy od 1663 roku.

53 Tylko tetry moskiewskie po 1663 roku.

54 Tylko w tetrach M. Ślozki.

55 Druki moskiewskie, lwowskie, wileński i kijowskie.

56 Pamięć ta została pominięta $\mathrm{w}$ tetrach moskiewskich $\mathrm{z}$ lat 1553/54, 1627 i 1628, wileńskim (z 1600 roku) i wszystkich lwowskich.
}

porównywanych tetraewangeliach wymienione zostało tylko święto narodzenia Najświętszej Bogarodzicy. W dwóch tetrach kijowskich (z lat 1697 i 1712) zapisano ponadto prokimenony.

W dniu 9 września w Ewangelii kijowskiej i wszystkich porównywanych tetrach zapisano dzień pamięci św. Joachima i Anny. Ponadto tego dnia zapisano wspomnienie św. męczennika Seweriana tylko w tetrach kijowskich (z lat 1697 i 1712), zaś prepodobnego Józefa Wołockiego (zm. 1515 r.) w dwóch tetrach moskiewskich (z lat 1689 i 1703) oraz dwóch kijowskich (z lat 1697 i 1712).

W dniu 10 września w Ewangelii kijowskiej i wszystkich porównywanych tetraewangeliach zapisano pamięć Minodory, Mitrodory i Nimfodory.

W dniu 11 września w Ewangelii kijowskiej wymieniona została pamięć św. Teodory. W niektórych tetraewangeliach zapisano przy niej przymiotnik aleksandryjska (дєељандялйскїА $)^{57}$.

Dzień 12 września został w Ewangelii kijowskiej pominięty. Natomiast w trzech tetrach moskiewskich (z lat 1663, 1689 i 1703) oraz dwóch kijowskich (z lat 1697 i 1712) zapisano pamięć św. męczennika Antonoma.

W dniu 13 września w Ewangelii kijowskiej i wszystkich porównywanych tetraewangeliach zapisano wspomnienie konsekracji bazyliki Anastasis w Jerozolimie. Wigilia święta Podwyższenia Krzyża Pańskiego i pamięć męczennika Korneliusza Setnika zostały pominięte w Ewangeliach moskiewskich z lat od 1644 do 1663.

W dniu 14 września ${ }^{58} \mathrm{w}$ Ewangelii kijowskiej i wszystkich porównywanych tetraewangeliach wymienione zostało tylko święto Podwyższenia Krzyża Pańskiego. Tylko w dwóch tetrach kijowskich (z lat 1697 i 1712) i moskiewskiej z 1644 roku zapisano ponadto prokimenony.

W dniu 15 września w Ewangelii kijowskiej i wszystkich porównywanych tetraewangeliach wymieniona została tylko pamięć św. wielkiego męczennika Nikity.

W dniu 16 września w Ewangelii kijowskiej i wszystkich porównywanych tetraewangeliach wymieniona została tylko pamięć św. męczennicy Eutymii.

Dzień 17 września został w Ewangelii kijowskiej pominięty. We wszystkich porównywanych tetraewangeliach tego dnia zapisano pamięć św. Zofii i jej trzech córek, Wiery, Nadziei i Miłości (Luby).

Dzień 18 września został w Ewangelii kijowskiej pominięty. We wszystkich porównywanych tetraewangeliach tego dnia zapisano pamięć św. Eumeniusza Cudotwórcy, biskupa gortyjskiego.

Dzień 19 września został w Ewangelii kijowskiej pominięty. W porównywanych tetraewangeliach, poza moskiewskimi z lat 1644-1651, tego dnia zapisano pamięć: męczenników Trofima, Sabacjusza i Dorymedonta oraz śmierć księcia smoleńskiego i jarosławskiego Teodora razem z dziećmi Dawidem i Konstantym.

\footnotetext{
57 Został on pominięty w tetrach moskiewskich do 1651 roku, wileńskim i wszystkich lwowskich.

58 Przed i po 14 września w Ewangelii kijowskiej i porównywanych tetrach wymienione są soboty i niedziele związane ze Świętem Podwyższenia Krzyża Pańskiego.
} 
W dniu 20 września w Ewangelii kijowskiej i pozostałych porównywanych tetraewangeliach zapisano pamięć św. męczennika Eustachego, przy której podano dodatkowe informacje: и дляжини єго, и ижє с нинъ lub плакидты и ижє с нинт. Tylko w drukach moskiewskich (poza 1553/1554) i kijowskim w tym dniu zapisano również św. męczenników i cudotwórców czernihowskich księcia Michała i jego bojara Teodora.

Dzień 21 września został w Ewangelii kijowskiej pominięty. W porównywanych tetraewangeliach w tym dniu został wymieniony apostoł Kodrat z Magnezji. Tylko w tetrach kijowskim i moskiewskim z 1663 roku podano informację liturgiczną o zakończeniu święta Podwyższenia

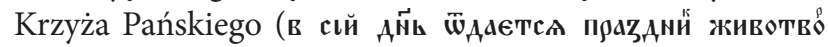
ко́та).

Dzień 22 września został w Ewangelii kijowskiej pominięty. W porównywanych tetraewangeliach w tym dniu został wymieniony święty męczennik Fokas, biskup Synopy. Pamięć proroka Jonasza została zapisana tylko w dwóch kijowskich tetrach (z lat 1697 i 1712), zaś św. Jonasza kapłana, ojca Teofana Hymnografa i Teodora Naznaczonego tylko w tetrze kijowskim z 1712 roku.

W dniu 23 września w Ewangelii kijowskiej oraz we wszystkich porównywanych tetrach zapisano poczęcie czcigodnego, chwalebnego i Proroka i Poprzednika i Chrzciciela Pańskiego Jana.

W dniu 24 września w Ewangelii kijowskiej oraz we wszystkich porównywanych tetrach zapisano pamięć św. pierwszej męczennicy równej apostołom Tekli.

W dniu 25 września w Ewangelii kijowskiej oraz we wszystkich porównywanych tetrach zapisano pamięć św. matki Eufroryny oraz śmierci św. Sergiusza z Radonieża.

W dniu 26 września w Ewangelii kijowskiej oraz we wszystkich porównywanych tetrach zapisano pamięć odejścia św. apostoła i ewangelisty Jana Teologa.

Dzień 27 września został w Ewangelii kijowskiej pominięty. Tylko w niektórych porównywanych tetraewangeliach w tym dniu został wymieniony św. męczennik Kallistrat i Jego towarzysze ${ }^{59}$ oraz mnich Sabacjusz Sołowiecki ${ }^{60}$.

W dniu 28 września w Ewangelii kijowskiej oraz we wszystkich porównywanych tetrach zapisano pamięć św. Charytona Wyznawcy. Jednak tylko w tetraewangeliach przed lub po imieniu zapisano rzeczownik испов Адника.

Dzień 29 i 30 września został w Ewangelii kijowskiej pominięty. We wszystkich porównywanych tetraewangeliach w dniu 29 września zapisano pamięć św. Cyriaka pustelnika, zaś w dniu 30 września pamięć św. męczennika Grzegorza, biskupa Armenii. Tylko w jednym tetrze moskiewskim z 1703 roku w ostatnim dniu września wspomina się św. Grzegorza Pielszemskiego (ижє на пєлшн' өъц').

O ile porównanie wrześniowych świąt i świętych Ewangelii kijowskiej z aparatem liturgicznym osiemnastu tetraewangelii nie pozwala na wyciągnięcie konkretnych

\footnotetext{
$59 \mathrm{~W}$ tetraewangeliach moskiewskich po 1663 roku (1663, 1689 i 1703) oraz dwóch kijowskich (1697 i 1712).

$60 \mathrm{~W}$ tetraewangeliach moskiewskich po $1644 \mathrm{rok}(1644,1648,1651$, 1663, 1689 i 1703) oraz dwóch kijowskich (1697 i 1712).
}

wniosków, to jednak podane wcześniej niektóre przykłady mało popularnych tradycji liturgicznych - np. tej z 14 stycznia, występującej tylko w drukach kijowskich (z lat 1697 i 1712) - świadczyć mogą o wykorzystaniu kijowskiej tetraewangelii z 1697 roku (z pominięciem niektórych zawartych w niej informacji liturgicznych) przez drukarzy kijowskich podczas pracy nad składem Ewangelii z 1707 roku.

Cykl minejny wydanej z polecenia I. Mazepy w Kijowie w 1707 roku Ewangelii aprakosie pełnym, w porównaniu do wykorzystanych w badaniu 18 drukowanych do 1800 roku tetrów, jest dużo bardziej ubogi nie tylko w liczbę świąt i świętych, ale również dodatkowe informacje związane z miejscem wydarzeń (np. в Хон\$хъ ką osób (np. єก́па ньконидийскагш). Nie ulega wątpliwości, że ten wydany w 1707 roku w Kijowie w drukarni Ławry Peczerskiej jedyny ewangeliarz pełny zasługuje na szczegółowe studia tekstologiczne i liturgiczne.

\section{ANEKS \\ Wykaz świąt i świętych (z informacjami liturgicznymi) z Ewangelii Kijowskiej z 1707 roku w miesiącu wrześniu}

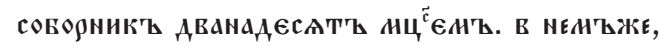
КОЕНУЖАШ ПЛАZАНИКУ ГА

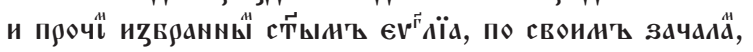

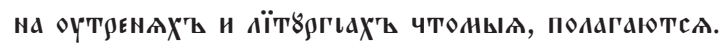

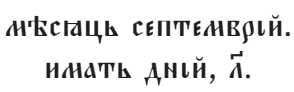

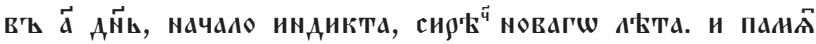

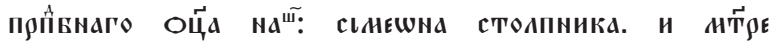

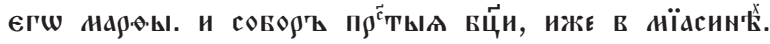

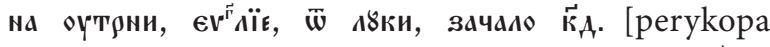

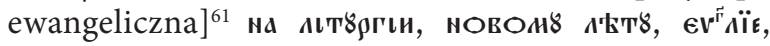

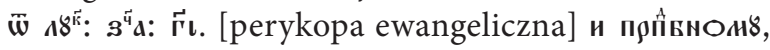

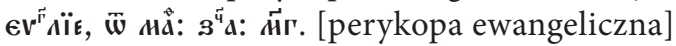

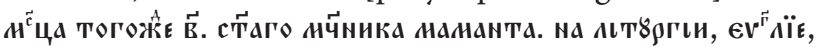

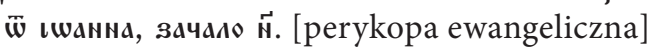

м

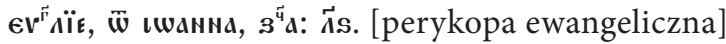

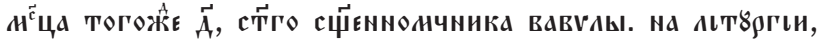

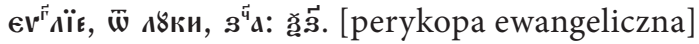

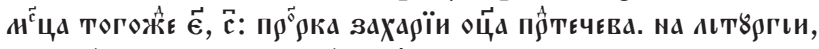

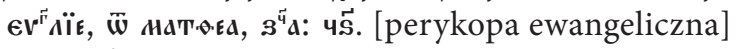

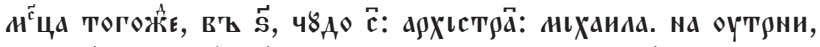

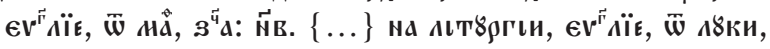
зАчАло: กิa. [perykopa ewangeliczna]

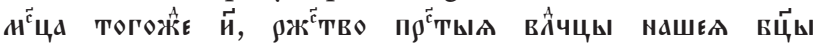

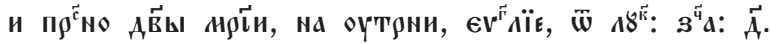

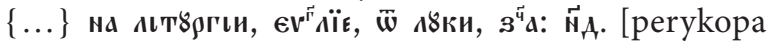
ewangeliczna]

${ }_{61}$ W nawiasach kwadratowych podano tylko informację o obecności lub braku tekstu perykopy ewangelicznej. Dokładna identyfikacja księgi (Ewangelii), rozdziału i wersetu może być przeprowadzona w oparciu o podanych przy każdym fragmencie ewangelicznym gławy. 
м

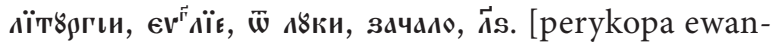
geliczna]

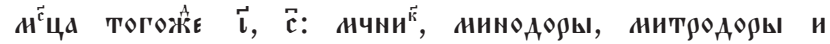

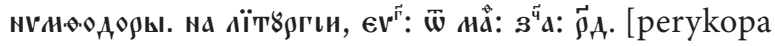
ewangeliczna]

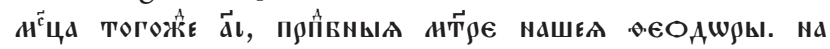

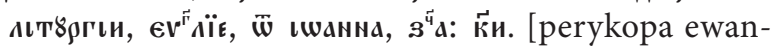
geliczna]

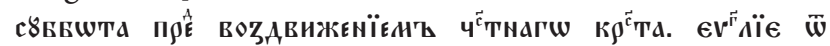

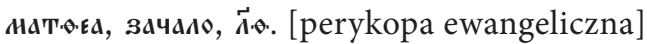

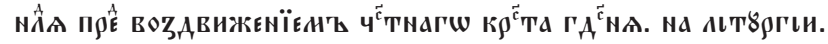

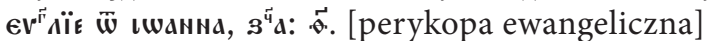

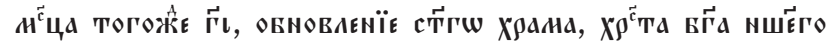

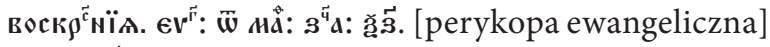

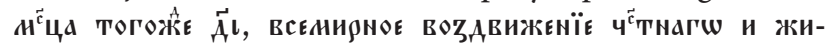
вотво

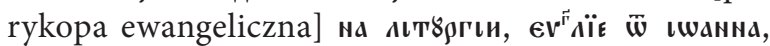
$3^{4} \mathrm{a}: \overrightarrow{2}$. [perykopa ewangeliczna]

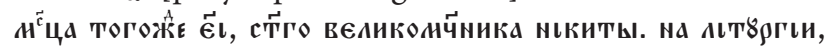

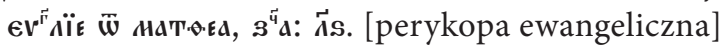

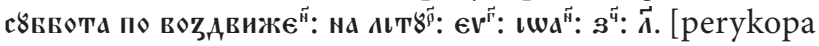
ewangeliczna]

нА̂े По во弓Авиже ewangeliczna]

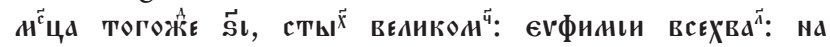

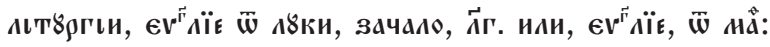

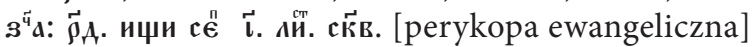

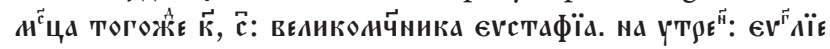

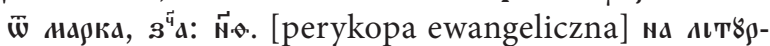

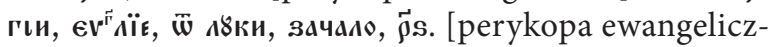
na]

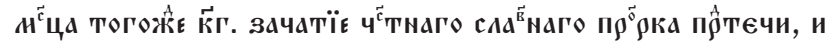
к $\rho^{\vec{c}}$ TAл เша"

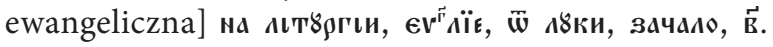
[perykopa ewangeliczna]

м $^{\vec{c}}$ ца тогожё ка.

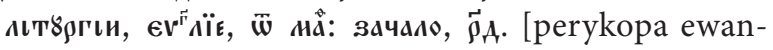
geliczna]

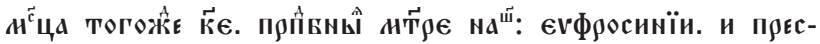

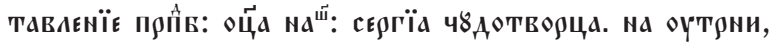
єv

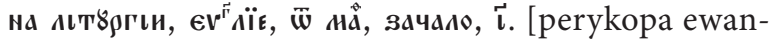
geliczna]

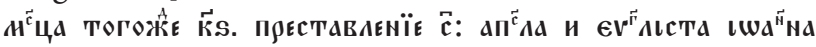

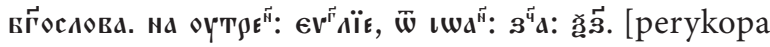

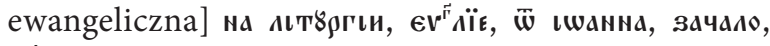
วُর. [perykopa ewangeliczna]

м

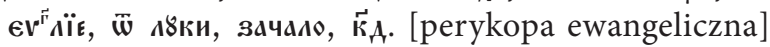

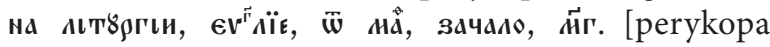
ewangeliczna]

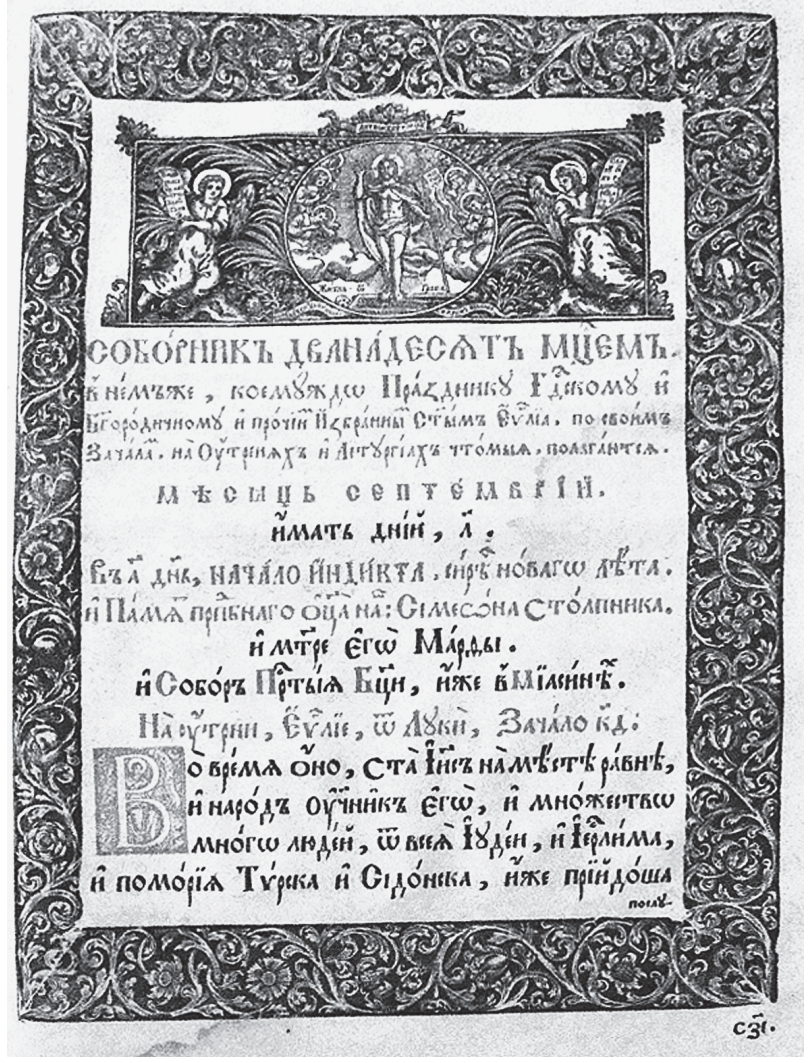

\section{Bibliografia}

Martinov J. (1863). Annus ecclesiasticus graeco-slavicus, Bruxellis.

Miklas H., Schnitter M. (1999). Kyrillomethodianische Miszellen Westliche Einträge in den älsten kirchenslavischen Kalendarien. Festschrift für Klaus Trost zum 65. Geburtstag. ed. E. Hansack, W. Koschmal, N. Nübler, R. Večerka (Die Welt der Slaven. Sammelbände/Sborniki, Vol. 5). München, 259-288.

Mironowicz A. (2001). Kościół prawosławny w dziejach dawnej Rzeczypospolitej. Białystok.

Ostapczuk J. (2010). Cerkiewnosłowiański przekład liturgicznych perykop okresu Paschalnego i święta Pięćdziesiątnicy w rękopiśmiennych ewangeliarzach krótkich, Warszawa.
Ostapczuk J. (2013). Sobotnie i niedzielne perykopy liturgiczne z Ewangelii Mateusza w cerkiewnosłowiańskich lekcjonarzach krótkich. Warszawa.

Ostapczuk J. (2015a). Новые фрагменты рукописных кириллических Евангелий из собраний Афонских монастырей. W Афонское Наследие, Научный Альманах, вып. 1-2/2015 (Материаль международной научной конференции «Русь и Абон: тысячелетие духовно-культурных связей», Чернигов, 28-29 ноября 2014 г.), Киев - Чернигов, 304-316.

Ostapczuk J. (2015b). Cyrylicki apostoł-ewangeliarz niedzielny z Drukarni Brackiej w Łucku (1640 r.). Rocznik Teologiczny, LVII, 2, 169-201. 
Вакалерийска С. (1994). Съвпадения и разлики в текста и в месецослова на два близки евангельски ръкописа: Кързоновото (Видинското) и Банишкото Евангелие. Palaeobulgarica, 1, 58-68.

Булашев Г. (1882). Месяцесловы святых при рукописных богослужебных книгах иерковно-археологического музея. Киев.

Гусева А.А. (1997). Идентификация экземпляров украинских изданий кирилловского шрифта второй половинь XVIIXVIII вв. Методические рекомендации. Москва.

Древнейшие русские святцы при Остромировом Евангелии. Христианское чтение, 1852, ч. 1, 485-517.

Жуковская Л.П. (1993). Еще о текстологии месяцеслова Евангелия (по датированным древнерусским апракосам XI-XII вв.). Труды Отдела древнерусской литературы, 48, 81-87.

Кекелидзе К.С. (1912). Іерусалимскій канонарь VII века. Тифилисъ.

Ковязина Н. (1997). Месяцеслов славянского апрвкосного Евангелия XI-XVI веков: сентябрь. Palaeobulgarica, 3, 31-52.

Ковязина Н. (1998). Стабильные памяти и евангельские чтения в славянском апракосном Меяцеслове XI-XVI вв (сентябрь). Slavistica Vilnensis, 51-60 (Kalbotyra 49 (2)), 51-61.

Коцева Е. (1995). Особенности календаря на Енинския Апостол. Palaeobulgarica, 1, 104-111.

Коцева Е. Атанасов А. (1991). Особености в съдържанието на Апостол № 882 от Народната Библиотека «Св. Кирил и Методий» в София. Кирило-Методиевски Студии, 8, София, 292-319.

Коцева Е. Атанасов А. (1993). Цариградският месецослов от 10 век и календари в български письмени паметници. W Хиляда и осемдесет години от смъртта на св. Наум Охридски, София, 214-241.

Лосева О.В. (1995). Месяцеслов Архангельского Евангелия 1092 г. W Архангельскому Евангелию 1092 года - 900 лет. Москва, 46-54.
Лосева О.В. (199а). Месяцесловы древнерусских Евангелий ХІ-ХІІ веков, Москва.

Лосева О.В. (199b). Русские праздники в древнейших церковных календарях. Русское средневековве, 5-59.

Лосева О.В. (2001а). Русские месяцесловы XI-XIV веков. Москва.

Лосева О.В. (2001b). Периодизация древнерусских месяцесловов XI - XIV в. Древняя Русь, 4, 14-36.

Лосева О.В. (2003). Праздники Святогробского Типикона в русских календарях XI-XII веков. Православный палестинский сборник, 100, 132-141.

Мещерский Н.А. (1997). О календаре Остромирова Евангелия. Вопросы языкознания, 5, 155.

Невоструев К.И. (1997). Исследование о Евангелии, писанном для Новгородского князя Мстислава Владимировича в начале XII века, в сличении с Остромировым списком, Галичским и двумя другими XII и одним XIII века. W Мстиславово Евангелие ХІІ века: Исследования. Ред. Курочкина О.В., Новиков Е.В., Горбунова Л.П., Москва, 5-649.

Сергий архиепископ (Спасскій). (1901). Полный месяцеслов Востока. Т. 1-2. Изд. 2. Владимиръ.

Скоморохова-Вентурили Л. (1985). Месяцеслов как памятник языка и культуры (на материале Церколезского Апостола и Баницкого Евнгелия). Полата книгописная, 14-15, 122-131.

Стефановић Д. (1989). Прилог проучвању месецослова XIII и XIV века. Јужнословенски филолог, 45, 140-152.

Тітов Хв. (1918). Типограбія Кіево-печерской Лавры. Историческій очеркъ (1606-1616-1916 г.2.), Т. 1 (1606-16161721 г.г.), Кіевъ.

Шевчук В. (2012). Просвіченний володар. Іван Мазепа як будивничий Козацкої держави $і$ як літературний герой, Київ. 